Izabela Franckiewicz-Olczak (i) https://orcid.org/0000-0001-7059-9678

Uniwersytet Łódzki, Instytut Socjologii

e-mail: i.franckiewicz@uni.lodz.pl

Anna Grunwald (współpraca)

Państwowe Muzeum Etnograficzne w Warszawie

e-mail: anna.grunwald@ethnomuseum.pl

\title{
Badanie publiczności jako integralny element tworzenia ekspozycji czasowej. Wystawy Teens Love Design i Rzeczy kultowe Panstwowego Muzeum Etnograficznego w Warszawie
}

Abstract

Audience Research as an Integral Element of Creating a Temporary

Exhibition. Teens Love Design and Iconic Things - the National Ethnographic Museum's Exhibitions

The aim of the article is to focus on, connected with democratization, culture' s changes. These changes entail modification of culture research. On that theoretical base the Teens Love Design and Iconic Things projects conduct by National Ethnographic Museum are presented. The research in these projects help to work out the shape of the temporary exhibitions.

Keywords: audience research, culture research, Teens Love Design, Iconic Things, democratisation of culture

Słowa kluczowe: badania publiczności, badania kultury, Teens Love Design, Rzeczy kultowe, demokratyzacja kultury 
Zmiany w badaniach kultury są wtórne względem przekształceń w obrębie samej kultury, w wyniku których punkt ciężkości przesuwa się z nadawców i artefaktów kultury, na jej odbiorców. Zmiany te, na marginesie, stają się przyczyną skonfundowania części środowiska muzealników, którzy misję muzeów w większym stopniu utożsamiają z przechowywaniem dziedzictwa niż zaspokajaniem bieżących potrzeb partycypacyjnych odbiorców [por. Franckiewicz-Olczak 2017: 110-111]. Celem artykułu jest analiza możliwości czynnego włączania publiczności w proces tworzenia wystaw przez objęcie jej procesem badawczym. Do ich zobrazowania w artykule zostaną wykorzystane przykłady projektów „Teens Love Design 2017 - Młodzieżowy Sektor Kreatywny” i „Rzeczy kultowe” realizowanych przez Państwowe Muzeum Etnograficzne (PME) w Warszawie w latach 2017 i 2018-2020 w ramach dotacji z Ministerstwa Kultury i Dziedzictwa Narodowego oraz Samorządu Województwa Mazowieckiego. Działania podejmowane przez PME interpretować można w kontekście procesów demokratyzacji kultury. Warto również, co postaramy się uczynić, przyjrzeć się im z perspektywy zmian w podejściu do badania publiczności w polskiej tradycji nauk społecznych.

\section{Przeksztalcenia w obrę̧bie kultury}

Stosunek do badań odbiorców kultury ewaluował jednocześnie ze zmianami samej kultury, a także podejścia do niej i teoretycznego nad nią namysłu. Zmianom w obszarze kultury towarzyszyły przekształcenia teoretycznej ich recepcji, a w konsekwencji przekształcenia w podejściu do odbiorców. Rozwijająca się w okresie międzywojennym krytyka kultury masowej traktowała jej odbiorcę jako barbarzyńcę, którego należy raczej cywilizować, niż pytać o opinię. Jose Ortega y Gasset [1932] ubolewał wręcz nad uginaniem się elit pod naporem niewykształconych mas. Obok Gasseta w kontekście tym można przywołać również chociażby T.S. Eliota czy Franka Raymonda Leavisa. Dalsza krytyka związana z okresem powojennym, wycelowana głównie w uprzemysłowienie i uproduktowienie kultury, wywodziła się między innymi ze szkoły frankfurckiej i znalazła najbardziej rezonujący wyraz w Dialektyce oświecenia Maxa Horkheimera i Theodora W. Adorno [1947]. Pod wpływem doświadczeń II wojny światowej akcentowano wówczas totalitaryzujący potencjał kultury masowej. Obawy tego rodzaju pojawiły się u C. Wrighta Millsa, Adorno, Horkheimera czy Herberta Marcuse'a.

Na gruncie polskim - z nastawieniem nie tyle krytycznym, ile teoretycznym, aczkolwiek wciąż wartościującym - problematykę kultury poruszała między innymi Antonina Kłoskowska [2005]. To hierarchizujące, stawiające wyraźne rozróżnienie na kulturę wysoką i niską, podejście z wyraźnym deprecjonowaniem kultury niskiej, stopniowo ewaluowało w kierunku bardziej neutralnego podziału na kulturę masową i elitarną. Ta pierwsza zaś w celu zniwelowania negatywnych konotacji z bierną 
masą odbiorców, ostatecznie została nazwana kulturą popularną (choć sam termin został użyty w 1944 roku przez krytyka kultury masowej Dwighta Macdonalda). Zmianę nastawienia do kultury popularnej przynoszą lata siedemdziesiąte XX wieku wraz z publikacjami Herberta Juliusa Gansa [1974] i Alana Swingewooda [1977]. Problematyka ta wciąż nie traci na ważności, a kultura popularna budzi niekiedy skrajne emocje. Celem naszej analizy nie jest - szeroko omówiona w literaturze polskiej i światowej - kwestia zmian w podejściu do kultury. W kontekście omawianej tematyki istotne jest obecne stadium kultury, wynikające z procesów jej demokratyzacji [por. Mannheim 1956]. Przytoczony autor analizował problematykę demokratyzacji kultury w ujęciu historycznym, dostrzegał występujące naprzemiennie fazy niwelowania i zwiększania dystansów społecznych. Demokratyzacja kultury, jego zdaniem, polega na zmniejszaniu się pionowych dystansów społecznych. Interpretując Mannheima, można dodać, że w zdemokratyzowanej kulturze sztuka nie jest ani w obszarze jej tworzenia, ani odbioru zarezerwowana dla określonych grup społecznych, jest efektem codziennego trudu, a nie unikatowego geniuszu wybitnych jednostek. Jak można zaobserwować, obecnie zdemokratyzowana kultura znajduje się w fazie zaawansowanej dedystancjacji. Procesami demokratyzacji kultury określamy na potrzeby tego opracowania zmiany w dostępie do treści kultury odbiorców, znoszenie dystansów pomiędzy kulturą wysoką a niską i last but not least dowartościowanie roli odbiorcy w działaniach na obszarze kultury. Procesom tym w obszarze dyskursywnym towarzyszy przejście w refleksji nad kulturą od dychotomicznego podziału na kulturę niską i wysoką, poprzez podział na kulturę wysoką elitarną i masową, zastąpienie kategorii kultury masowej, kulturą popularną, która w swym obecnym stadium, również dzięki nowym technologiom, może być bardziej zindywidualizowana, personalizowana i tworzona przez odbiorców. W kulturze współczesnej odbiorcy zachęcani są do aktywnego uczestnictwa, które polega nie tylko na odbiorze, ale także tworzeniu lub współtworzenia przekazów artystyczno-kulturalnych [por. Franckiewicz-Olczak 2016].

Przedstawionym przeobrażeniom w podejściu do kultury i jej odbiorców towarzyszą zmiany w badaniach prowadzonych nad kulturą. Podstawowym wymogiem badań społecznych jest ich obiektywność i neutralność. Trudno się jednak oprzeć wrażeniu, że zajmowanie się wybranym obszarem problemowym, odpowiednie postawienie pytań problemowych, określenie wskaźników i wreszcie dobór respondentów, umożliwia formułowanie wniosków określonego rodzaju, kształtując tym samym horyzont refleksji teoretycznej w przypadku badań akademickich oraz zakres wdrożeń w przypadku badań stosowanych. Choć oba rodzaje badań z zasady służą różnym celom - pierwsze rozwojowi/przyrostowi wiedzy, drugie aplikowaniu w praktyce określonych rozwiązań - obecnie wydaje się, że jest im do siebie bliżej niż w wieku XX. Wynika to z postępującego procesu demokratyzacji tym razem nauki i wiedzy, pedagogizacji życia społecznego [szerzej zob. Czyżewski, Marynowicz-Hetka, Woroniecka 2013], „uwiedzowienia” społeczeństwa z jednej strony, 
a z drugiej - z demokratyzacji kultury. Badania akademickie, coraz częściej finansowane ze środków grantowych, służą, przynajmniej pośrednio, celom wdrożeniowym, ich wyniki są powszechnie udostępniane i podawane w przystępnej, nierzadko uproszczonej formule. Jednocześnie coraz częściej do środowisk uniwersyteckich zwracają się instytucje kultury z prośbą o realizację badań.

Popularyzacja wyników badań stanowi jeden z elementów „uwiedzowienia” społeczeństwa, które Karol Franczak definiuje jako proces:

w którym specjaliści z różnych dziedzin zajmują się dostarczaniem odbiorcom szeroko zrozumiałych opisów, egzegez i objaśnień. Wiedza wytwarzana w polu nauki lub w ramach refleksji eksperckiej coraz bardziej natarczywie pośredniczy w tłumaczeniu złożonej rzeczywistości społecznej [Franczak 2013: 69].

Procesy te ogniskują szerokie grono zarówno krytyków jak i entuzjastów. Z jednej strony bowiem poziom społecznie dystrybuowanej wiedzy upraszczany bywa do poziomu informacji poradnikowych służących rozwiązywaniu bieżących problemów w zestandaryzowany sposób, przy jednoczesnym utrzymywaniu adresatów tejże wiedzy w przekonaniu o ich eksperckości w obszarze, w którym pozyskali ową spłaszczoną wiedzę. Z drugiej jednak strony uprzystępnianie wiedzy, jej popularyzacja, nawet jeśli dokonuje się kosztem pewnych uproszczeń i generalizacji, stwarza potencjalne możliwości rozwoju zainteresowanych jednostek, przyrostu informacji, podniesienia poziomu wiedzy w społeczeństwie.

Wskazane dylematy dotyczą również zarówno kwestii prowadzenia badań, jak $\mathrm{i}$ ich upowszechniania. Instytucje kultury coraz częściej motywowane są do realizacji badań we własnym zakresie, opartych na wiedzy potocznej lub zdobytej podczas kilkugodzinnych szkoleń. Tak ograniczone przygotowanie stawia pod znakiem zapytania rzetelność wyników, stanowi jednak pewien kompromis w sytuacji braku środków na zaangażowanie w proces badawczy specjalistów. Osobnym problemem jest uprzystępnianie wyników nawet rzetelnie przeprowadzonych badań. Modne jest obecnie redukowanie obszernych raportów do kilku infografik. I ponownie graficzne, redukcjonistyczne przedstawienie wyników ma większe szanse na dotarcie do odbiorców informacji i utrwalenie ich, jednak kosztem braku nadania rezultatom badania jakiegokolwiek kontekstu interpretacyjnego. Ambicją autorek nie jest rozwiązywanie przedstawionych dylematów, a jedynie zwrócenie uwagi na ich obecności w badaniach kultury. Niekwestionowanym atutem bieżącego stanu badań w obszarze kultury jest wzrost znaczenia odbiorców w analizach badawczych. 


\section{Badania kultury kiedyś}

Jeśli przyjrzeć się badaniom akademickim prowadzonym $\mathrm{w}$ Polsce $\mathrm{w}$ latach siedemdziesiątych i osiemdziesiątych, inspirowanym socjologią światową, uprawianą między innymi przez Pierre’a Bourdieu, to warto podkreślić, że skupiały się one na wyjaśnianiu relacji pomiędzy strukturą społeczną a kulturą symboliczną [Bokszański 2012: 52]. Podobnie drugi istotny obszar badawczy, związany ze zjawiskami społecznego odtwarzania kanonicznych tekstów kultury narodowej, oparty był na różnicach klasowych. Celem badań, jak zauważa Zbigniew Bokszański, było „prześledzenie w systematyczny sposób kulturowych aspektów zróżnicowania społecznego" [Bokszański 2012: 52]. Badano odbiór potoczny, który stawiano w opozycji do krytycznego, charakterystycznego dla wąskiego grona odbiorców. Badania zaś prowadzono w celu zweryfikowania kompetencji i umiejętności odczytań artefaktów kultury przez odbiorców, nie poddając pod ocenę ich czytelności, zrozumiałości i przystępności, co zrozumiałe o tyle, że analizy prowadzono, opierając się na dziełach składających się na kanon kultury polskiej (twórczość Adama Mickiewicza, Stefana Żeromskiego, Stanisława Wyspiańskiego). Badaniom prowadzonym między innymi przez Antoninę Kłoskowską i jej wychowanków należy przyznać niekwestionowalny wpływ na rozwój socjologii kultury w Polsce. Trzeba jednak zauważyć, że pozostając pod wpływem głównych światowych trendów, przyjmowały one - wciąż zresztą obecne w naukach społecznych - presupozycje zakładające, wartościujące podejście do kultury symbolicznej, postrzeganej jako autoteliczna. Nie sposób wyzbyć się wrażenia, że tak ujmowana kultura, a dokładniej kultura wysoka, w omawianych badaniach posiada charakter nobilitujący, a uczestniczenie w niej, podobnie jak właściwa recepcja, zależna jest od przynależności klasowej. Zależność ta wciąż jest obecna w refleksji nad uczestnictwem w kulturze i jej odbiorem. Dokonane zmiany społeczne spowodowały jednak, że wykształcenie, choć widoczna jest zależność pomiędzy jego poziomem a uczestnictwem w kulturze, coraz rzadziej w badaniach staje się zmienną kontrolną.

Osobnym świadectwem uczestnictwa w kulturze w latach siedemdziesiątych i osiemdziesiątych są prowadzone przez Główny Urząd Statystyczny masowe badania sondażowe dużych i reprezentatywnych próbek ogólnokrajowych, które jednak, jak zauważyła Kłoskowska, operując nielicznymi pytaniami i niekontrolowanymi wypowiedziami, pozwalają określić $\mathrm{z}$ dużym prawdopodobieństwem tylko jedną z zaproponowanych przez Stanisława Ossowskiego kategorię - wartości uznawane, czyli to, co uważane jest przez respondentów za godne szacunku, pożądania, realizacji, ale niekoniecznie jest rzeczywiście realizowane [Kłoskowska 1976: 72]. Warto również zauważyć, że w omawianym okresie zupełnie marginalizowane są badania nad kulturą popularną. 


\section{Badania kultury dziś}

Wzrost znaczenia kultury popularnej, odchodzenie od wartościującego podejścia w rozważaniach na temat kultury, zwrócenie się w politykach kulturalnych w kierunku przemysłów kulturalnych - wszystko to sprawia, że zmianie ulegają obszary badawcze, przedmioty analiz, wskaźniki i sposoby interpretacji wyników badań nad kulturą i uczestnictwem w niej. Zmiana ta wydaje się wręcz opresyjna dla instytucji kultury, które stają się zakładnikami frekwencyjności. Interpretacja wskaźnika, jakim jest poziom frekwencji, obecnie służy badaczom do oceny raczej działalności instytucji niż kompetencji ich publiczności.

Istotnym problemem w tej sytuacji jest przekonanie instytucji kultury o zasadności badań i możliwościach, jakie stwarzają one dla podmiotów badanych. Sytuacja w tym zakresie zmienia się dynamicznie. Jeszcze 10 lat temu instytucje kultury nie odczuwały potrzeby prowadzenia badań publiczności. Pojawiały się wówczas argumenty dwojakiego rodzaju. W pierwszej z optyk przedstawiciele instytucji uważali, że jako nadawcy kultury, posiadają misję, i ich celem jest kształtowanie potrzeb oraz gustów odbiorców, a nie odpowiadanie na nie, a także że kultura nie może naginać się pod presją gustu przeciętnego odbiorcy. Drugi rodzaj tłumaczenia sprowadzał się do przekonania, że instytucje znają swoich odbiorców, mają z nimi kontakt i nie potrzebują zewnętrznego arbitra w zakresie komunikacji z publicznością ${ }^{1}$. Obecnie coraz częściej zarządzający instytucjami kultury mają świadomość potrzeby badań, choć nadal pojawiają się głosy artykułujące lęk przed nimi. Taka postawa wybrzmiała na przykład bardzo mocno podczas warsztatów realizowanych w ramach progra-

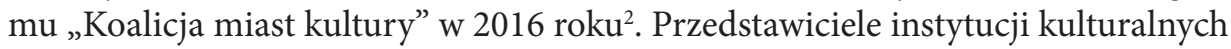
w Łodzi wyrazili wówczas obawy, że badania mogą służyć organizatorom jedynie w celach ewaluacyjnych i przynosić dla podmiotów negatywne konsekwencje. Pomimo pewnych ambiwalencji w ocenie sposobów wykorzystywania wyników badań wyraźnie widoczny jest trend ku świadomemu, profesjonalnemu zarządzaniu placówkami kultury, opartemu na rekomendacjach wynikających $\mathrm{z}$ badań, $\mathrm{w}$ tym sondowaniu publiczności. Nie jest istotne, w jakim stopniu wynika on z rzeczywistych przekonań zarządzających instytucjami, a w jakim z odgórnie narzucanych polityk kulturalnych. Osobną kwestią są również sposoby, w jakie instytucje kultury próbują sprostać postulatowi otwartości instytucji kultury i utrzymywaniu wysokiej frekwencji. Powszechnie znane są przypadki podejmowania działań zupełnie niezwiązanych z profilem działalności placówek, w celu jednorazowego przyciągnięcia do niej publiczności.

${ }^{1}$ Wskazane dwa rodzaje tłumaczeń zaczerpnięte są z rozmów z przedstawicielami kultury, prowadzonych w latach 2009-2012.

${ }^{2}$ Jedna $\mathrm{z}$ autorek tekstu, Izabela Franckiewicz-Olczak, prowadziła wskazane warsztaty. 
Wracając do zmian w kulturze, warto zasygnalizować, że rozwój kultury popularnej, kształtowanie się społeczeństwa wiedzy, rozwój mechanizmów partycypacyjnych, wiara w sprawczość jednostek i wiele innych tendencji obecnych w nowoczesnym społeczeństwie mają wpływ na stosunek do kultury współczesnej. Obcowanie z kulturą przestaje być domeną czasu wolnego, sferą relaksu, a staje się obszarem budowania własnego wizerunku, podstawą awansu społecznego, przestrzenią rozwoju tak pożądanej współcześnie kreatywności. Aktywność kulturalna w internecie prowadzi do zaniku tradycyjnego podziału na nadawców i odbiorców treści kulturalnych. Tradycyjne instytucje kultury, starając się wyjść naprzeciw potrzebom odbiorców, coraz częściej podejmują działania na rzecz ich aktywnego włączenia w działania instytucji poprzez różne formy interaktywności. Jednocześnie, poprzez choćby badania, starają się w odbiorcach budzić przekonanie na temat ich sprawczości i wpływie na charakter instytucji. Proces badawczy coraz częściej połączony zostaje z procesem twórczym, a publiczność staje się częścią obu z nich.

\section{Teens Love Desighn i Rzeczy kultowe}

W dalszej części tekstu opisane zostaną projekty Teens Love Design i Rzeczy kultowe realizowane przez Państwowe Muzeum Etnograficzne, które stanowią egzemplifikację łączenia komponentu badawczego z tworzeniem wystawy. Specyfika muzeum etnograficznego sprawia, że działalność badawcza jest elementem funkcjonowania tego rodzaju instytucji. PME rozszerza swoją działalność badawczą, stawia na eksperyment, wychodzi zdecydowanie poza ramy etnografii, ale również poza tradycyjnie pojmowane badanie publiczności. Badania w omawianych projektach stają się elementem nie tyle planowania wystaw, ile ich rzeczywistego tworzenia.

Projekt „Teens Love Design 2017 - Młodzieżowy Sektor Kreatywny” opracowany przez Annę Grunwald z Państwowego Muzeum Etnograficznego w Warszawie oraz Beatę Kuracińską ze szczecińskiej Fundacji Artmosphere uzyskał dotację w ramach pierwszej edycji programu Ministerstwa Kultury i Dziedzictwa Narodowego „Rozwój Sektorów Kreatywnych” oraz Samorządu Województwa Mazowieckiego. Realizowany w 2017 roku, przewidywał uruchomienie w Państwowym Muzeum Etnograficznym w Warszawie „centrum kompetencyjnego” młodzieżowych sektorów kreatywnych. Powstało ono w procesie projektowania interdyscyplinarnego i sieciowania - współpracy młodzieży z Polski i Grecji oraz dzięki udziałowi ekspertów reprezentujących różne sektory i branże kreatywne. Narzędziem kreacji i wdrożenia projektu był między innymi proces design thinking, gdzie współpraca młodzieży między sobą oraz młodzieży i ekspertów zapewniała autentyczną wymianę kompetencji, wiedzy, doświadczeń oraz umiejętności.

W procesie badawczym, za który odpowiedzialne było Biuro Badań Społecznych Question Mark, prowadzonego symultanicznie z tworzeniem wystawy, realizowane 
były obserwacje uczestniczące podczas warsztatów wydobywczych (obserwacja $\mathrm{z}$ listą poszukiwanych informacji) $\mathrm{N}=4$, sesje warsztatowo-fokusowe $\mathrm{z}$ uczestnikami obserwowanych warsztatów wydobywczych, z zastosowaniem metodologii design thinking $\mathrm{w}$ Warszawie i Atenach $\mathrm{N}=2$. Celem badania było rozpoznanie, co fascynuje współczesną młodzież. W ramach procesu badawczego poddano weryfikacji hipotezy zakładające, że młodzi ludzie interesują się food designem (jedzenie i jego przygotowanie staje się ważnym elementem estetyzacji życia), modą, filmem i nowymi technologiami. Tak sformułowane cele służyły odpowiedzi na pytanie, jak powinna wyglądać wystawa „TEEN-AGE”, jakie poruszać problemy, na jakie potrzeby młodzieży odpowiadać. Rezultatem procesu badawczego były rekomendacje/ wskazówki do przygotowania wystawy wraz z instalacją interaktywną wieńczącą projekt. Projektantami wystawy i instalacji hash2ash był kolektyw Pan Generator. Pośród rekomendacji znalazła się między innymi sugestia, by instalacja, niezależnie od tematyki, skłaniała do działań niecodziennych, może takich, które już nie są wykonywane (wykonują je maszyny, należą do obszaru zlecanego zewnętrznie). Praca interaktywna, jak ustalono w wywiadach, powinna dać szansę do „wyrażenia się", powinna być nieskomplikowana, ponieważ badanych interesują rzeczy proste, możliwość zrobienia czegoś z niczego, niestandardowe rozwiązania [Question Mark 2017: 15]. Artyści stworzyli instalację, która nawiązuje do kultury selfie i lęku przed utratą na stałe cyfrowych zapisów naszego życia w wyniku awarii technicznych, nietrwałości systemów przechowywania danych czy też po prostu przestarzałości niegdysiejszych formatów plików.

Wystawa „TEEN-AGE” z instalacją hash2ash prezentowana była na przełomie roku 2017 i 2018 w Państwowym Muzeum Etnograficznym w Warszawie oraz na Athens Digital Arts Festiwal w Atenach (Grecja) w dniach 24-27 maja 2018. Sama instalacja hash2ash została zgłoszona przez artystów projektantów na SXSW - największym festiwalu kultury na świecie w Austin w Teksasie (USA), skąd otrzymała dotację, także dzięki wsparciu Instytutu Adama Mickiewicza oraz Ambasady RP w Waszyngtonie oraz Instytutu Kultury Polskiej w Nowym Jorku, prezentowana była w Austin w marcu 2019 roku. Od maja do czerwca instalacja hash2ash pokazywana była w Muzeum Narodowym we Wrocławiu podczas 18. Biennale Sztuki Mediów WRO 2019 CZYNNIK LUDZKI / HUMAN ASPECT organizowanym przez Fundację WRO Centrum Sztuki Mediów.

Obecnie PME realizuje projekt „Rzeczy kultowe” dofinansowany przez Ministerstwo Kultury i Dziedzictwa Narodowego na lata 2018-2020 ze środków Funduszu Promocji Kultury w ramach programu „Edukacja kulturalna” oraz przez Samorząd Województwa Mazowieckiego. Projekt ma stworzyć warunki do interdyscyplinarnej dyskusji z udziałem publiczności poświęconej zjawisku kultowości oraz wyłonienia rzeczy i idei kultowych, które w procesie partycypacyjnych animacji publiczności zostaną zaprezentowane, $\mathrm{z}$ towarzyszącym im kontekstem, na wystawach ze specjalnym, włączającym programem działań edukacyjnych. Projekt ma zwrócić 
uwagę publiczności na arcyciekawy i angażujący obszar rzeczywistości, jakim jest kultowość i przełomowość pewnych zjawisk kulturowych, który podlega badaniom etnograficznym, a nie jest kojarzony jednoznacznie z tradycyjną etnografią. Działanie to ma także na celu rozszerzenie zasięgu obszarów kulturowych, z którymi w świadomości odbiorców łączy się muzeum etnograficzne.

W ramach działań o charakterze badawczym podejmowanych przez Biuro Badań Społecznych Question Mark, w 2018 roku zrealizowano badanie ilościowe CAWI na próbie $\mathrm{N}=313$ oraz badanie jakościowe (zogniskowane wywiady grupowe, tzw. fokusy) w liczbie trzech. Celem badań było oszacowanie potocznego znaczenia kultowości. W ramach konceptualizacji badania sformułowano następujące pytania badawcze: Co kategoria kultowości oznacza dla badanych?; Jakie budzi skojarzenia?; Co dla różnych pokoleń Polek i Polaków jest kultowe?; Jakie przedmioty określają jako kultowe i dlaczego? W 2019 roku zrealizowano badanie techniką wywiadu kwestionariuszowego z uczestnikami Nocy Muzeum w PME podczas jednej z wystaw zorganizowanych $w$ ramach omawianego projektu $\mathrm{N}=102$. Dodatkowym obszarem badawczym w 2019 roku było postrzeganie międzypokoleniowe kultowości. Celem badania była między innymi odpowiedź na pytanie: Co poszczególne grupy wiekowe (młodzież, dorośli i seniorzy) sądzą o tym, co jest kultowe dla pozostałych grup? (na przykład co młodzi myślą o przedmiotach kultowych dla dorosłych i seniorów).

$\mathrm{Z}$ badania wyłania się obraz kultowości jako fenomenu kojarzonego $\mathrm{z}$ popularnością, historią, dzieciństwem, legendarnością i kulturą. Z całą pewnością jest zakorzeniona w danym czasie. Są to przedmioty wyjątkowe i innowacyjne. Badani przyznali, że kultowość jest złożonym procesem, którego nie da się jednoznacznie ulokować w teraźniejszości, przyszłości bądź przeszłości. To pewne zjawisko, zawieszone w szczególności między tym, co było kiedyś, a tym, co jest teraz. Badani wskazali wiele przedmiotów, które uważają za kultowe [Question Mark 2018: 5].

Poza częścią stricte badawczą projekt pozwolił na podjęcie dyskusji środowiskowej, rezonującej publicznie, na temat kultowości oraz rzeczy i idei kultowych. Rezultatem pierwszego roku projektu była wystawa efemeryczna prezentowana w Państwowym Muzeum Etnograficznym w Warszawie w okresie maj-czerwiec $2019 \mathrm{roku}$, prezentująca $\mathrm{w}$ formie instalacji rzeczy, które respondenci podczas badań uznali za kultowe.

\section{Wnioski}

Zaproszenie odbiorców do współtworzenia wystawy staje się coraz częściej stosowaną praktyką instytucji muzealnych. W 2016 roku w Muzeum Narodowym w Warszawie dzieci wcieliły się w rolę kuratorów w projekcie „W muzeum wszystko wolno”, na przełomie 2018 i 2019 roku w oddziale Muzeum Sztuki w Łodzi pokazywana była wystawa „Jak to widzisz?", podczas której publiczność w ramach plebiscytu 
zadecydowała o wyborze prac na ekspozycję. Pogłębione badania prowadzone przez PME idą jednak krok dalej, nie chodzi w nich o wybór artefaktów, a o wspólne wypracowanie stanowiska w określonej kwestii: tego, co obecnie definiuje młodzież w przypadku „Teens Love Design”, czy postrzegania kultowości w projekcie „Rzeczy kultowe". Uczestnicy badań w pierwszej kolejności skłaniani są do refleksji na dany temat, a dopiero następnie badanie wchodzi w fazę konkretyzacji, w czasie której wyłania się kształt wystawy, na który ostateczny wpływ ma uczestniczący w projekcie kurator. W trakcie projektów wytwarzana jest wiedza, która wpływa nie tylko na charakter wystawy, ale także na uczestników projektu i jego odbiorców.

Projekty realizowane przez PME są progresywne we włączaniu odbiorców w tworzenie wystaw, czynią to jednak w sposób niezwykle przemyślany. Oddają odbiorcom w znacznej mierze kontrolę nad kształtem wystawy, aczkolwiek kosztem ich zaangażowania. Zmuszają uczestników badań do głębokiego namysłu, motywowania swoich opinii i wyborów. Tym samym idą nieco pod prąd wobec postaw typowych dla kultury współczesnej, w której zwykły „like” czy „łapka w górę” są wystarczającym komentarzem dla otaczającej rzeczywistości.

Prowadzone przez PME i inne podmioty badania publiczności stanowią dowód nobilitującej zmiany w podejściu do odbiorców, którzy przestają być rozliczani ze swoich kompetencji odbiorczych, a stają się podmiotem doradczym dla instytucji kulturalnych. Prowadząc badania opinii, potrzeb i preferencji odbiorców, należy zdawać sobie sprawę, że wdrażanie ich wyników wpływa na kulturę. W ten sposób obecne formy badania kultury są skutkiem zmian w kulturze, ale również czynnikiem zmianę wywołującym. Tym bardziej więc ważne jest, by utrzymywać wysokie standardy badawcze.

\section{Bibliografia}

Bokszański Z. (2012), Antoniny Kłoskowskiej teoria i socjologia kultury, „Przegląd Socjologiczny", t. 61 , s. $47-54$.

Czyżewski M., Marynowicz-Hetka E., Woroniecka G. red. (2013), Pedagogizacja życia społecznego, „Societas Communitas”, nr 2 (16), s. 178-189.

Franckiewicz-Olczak I. (2016), Sztuka interaktywna, Warszawa: Oficyna Naukowa.

Franckiewicz-Olczak I. (2017), Nowe media w muzeum. Demokratyzacja kultury a unifikacja muzeów i aktywizacja odbiorców, „Studia Sociologica”, IX, vol. 1, s. 106-114.

Franczak K. (2013), „Uwiedzowienie” sztuki. Problem intelektualizacji współczesnych działań artystycznych, „Kultura i Społeczeństwo”, nr 1, s. 69-84.

Gans H.J. (1974), Popular Culture and High Culture: An Analysis and Evaluation of Taste, New York: Basic Books.

Horkheimer M., Adorno Th.W. (2010), Dialektyka oświecenia. Fragmenty filozoficzne, tłum. M.J. Siemek, Warszawa: Wydawnictwo Krytyki Politycznej. 
Kłoskowska A. (1976), Potoczny odbiór literatury na przykładzie utworów Żeromskiego, „Pamiętnik Literacki” nr 67 (1), s. 65-91.

Kłoskowska A. (2005), Kultura masowa, Warszawa: Wydawnictwo Naukowe PWN.

Mannheim K. (1956), Essays on the Sociology of Culture, London: Routledge and Kegan Paul. Ortega y Gasset J. (2016), Bunt mas, tłum. P. Niklewicz, Zakrzewo: Replika.

Ossowski S. (1967), Konflikty niewspótmiernych skal wartości, [w:] S. Ossowski, Dzieła, t. 3: Z zagadnień psychologii społecznej, Warszawa: Państwowe Wydawnictwo Naukowe.

Question Mark (2017), Teens Love Design - raport z warsztatów, Łódź: Biuro Badań Społecznych Question Mark.

Question Mark (2018), Rzeczy kultowe - raport z badań, Łódź: Biuro Badań Społecznych Question Mark.

Swingewood A. (1977), The Myth of Mass Culture, London: The Macmillan Publishers. 